УДК 621.757:621.7.08

doi:10.20998/2413-4295.2019.05.06

\title{
INFLUENCE OF STRUCTURAL COMPONENTS PLACEMENT ON CASTING TECHNOLOGICAL DAMAGES FORMATION
}

\author{
J. M. KUSYJ ${ }^{*}$, V.G. TOPILNYTSKYJ ${ }^{2}$ \\ ${ }^{1}$ Mechanical Engineering Department, National University «Lviv Polytechnic», Lviv, UKRAINE \\ ${ }^{2}$ Machines Designing and Exploitation Department, National University «Lviv Polytechnic», Lviv, UKRAINE \\ 'e-mail:jarkym@ukr.net
}

ABSTRACT The technological processes designing main criterion are identified. The reliability parameters: infallibility, durability, repairability, preservation are described with machine part life cycle's substages and stages are described. The reliability support principles of difficult engineering systems for mechanical engineering production are analyzed. The insufficient researches level regarding influence of casting's structural components on defects formation on it surface is argued. The reliability varieties are considered, its place in the machine part life cycle's structure is identified and mathematical dependences for potential reliability definition are suggested. Inexpediency of potential reliability using as the part condition forecasting's criterion during it machining is justified. The blanks operations importance in the technological process planning structure of cast blanks is confirmed. The mathematical dependence for technological processes infallible implementation's estimated probability (the technological process reliability coefficient) is confirmed. The defects types and its formation mechanisms for blanks are analyzed. The casting defects main types: burnt-on sands, cavities, flashes and cracks are characterized. The deficiencies role as surface layer's infringements during parts work in machine is installed. The parameters for the deficiencies control according to ISO 8785: 1998 are presented. The metal destruction phases during machining are considered. It is installed that big angle grains boundaries have an important role in technological damages and processes of alloys destruction situating between grains boundaries formation. The material damageability degree evaluation's modern conceptions as the operating time result of direct and indirect measurements are considered and its main deficiencies are specified. The LM-hardness method for definition of the castings damageability $W$ as part infallibility parameter is presented. The technological fixture and the experimental researches execution and implementation technique are described. The received results justification and analysis are presented. The further researches directions are scheduled.

Keywords: technological process; reliability; infallibility; casting; technological damage; damageability

\section{ВПЛИВ РОЗМІЩЕННЯ ЕЛЕМЕНТІВ КОНСТРУКЦІї НА ФОРМУВАННЯ ТЕХНОЛОГІЧНИХ ПОШКОДЖЕНЬ ВИЛИВКА}

\section{Я. М. кУСИЙ' В.Г. ТОПІЛЬНИЦьКИЙ}

\author{
${ }^{1}$ кафедра технологї̈ машинобудування, Національний університет “Львівська політехніка”, Львів, УКРӒ̈НА \\ ${ }^{2}$ кафедра проектування та експлуатації машин, Національний університет “Львівська політехніка”, Львів, УКРАЇНА
}

\begin{abstract}
АНОТАЦІЯ Встановлено основні критерї проектування технологічних прочесів. Описано зв'язок показників надійності: безвідмовності, довговічності, ремонтопридатності, збережливості із етапами та стадіями життєвого циклу виробу. Проаналізовано принципи забезпечення надійності складних технічних систем для машинобудівного виробництва. Аргументовано на недостатньому рівні досліджень стосовно впливу розміщення конструктивних елементів виливка на формування дефектів на його поверхні. Розглянуто різновиди надійностей, встановлено їх місие у структурі життєвого циклу виробу та приведено математичні залежності для визначення потенційної надійності. Обтрунтовано недоцільність використання потениійної надійності в якості критерію прогнозування стану виробу під час його виготовлення. Підтверджено вагомість заготівельних операчій у структурі технологічних процесів механічного оброблення литих заготовок. Приведено математичну залежність для оцінки ймовірності безвідмовного здійснення технологічного процесу (коефіцієнта надійності технологічного процесу). Проаналізовано види дефектів і механізми їх формування для виливок. Охарактеризовано основні види дефектів литва: пригари, раковини, заливини та тріщини. Встановлено роль вад як порушень поверхневого шару при роботі деталей в складі виробів. Представлено параметри для контролю вад згідно ISO 8785: 1998. Розглянуто етапи руйнування металу під час обробки різанням. Встановлено, що важливу роль у формуванні технологічних пошкоджень і процесах міжзереного руйнування сплавів мають великокутові границі зерен. Розглянуто сучасні концепџї оцінки ступеню пошкоджуваності матеріалу як напрацювання за результатами прямих $i$ непрямих вимірювань та вказано їх основні недоліки. Представлено метод LM-твердості для визначення пошкоджуваності виливків $W$ як характеристики безвідмовності виробу. Описано технологічне оснащення та методику проведення $i$ здійснення експериментальних досліджень. Представлено обгрунтування та проаналізовано отримані результати. Намічено шляхи подальиих досліджень.
\end{abstract}

Ключові слова: технологічний прочес; надійність; безвідмовність; лита заготовка; технологічне пошкодження; пошкоджуваність

\section{Introduction}

The main criteria of technological process planning are specifications support and minimum parts manufacturing cost. The reliability parameters, which are occurred during parts exploitation, are usually disregarded [1-5]. 
The reliability parameters: infallibility, durability, repairability, preservation connect with all machine part life cycle's substages and stages in particular and machines as a whole (fig. 1). The reliability parameters are laid at the parts designing. The reliability parameters are supplied at the parts manufacturing. The reliability parameters are appeared at the parts exploitation. Therefore the reliability problem is comprehensive $[1,2]$.

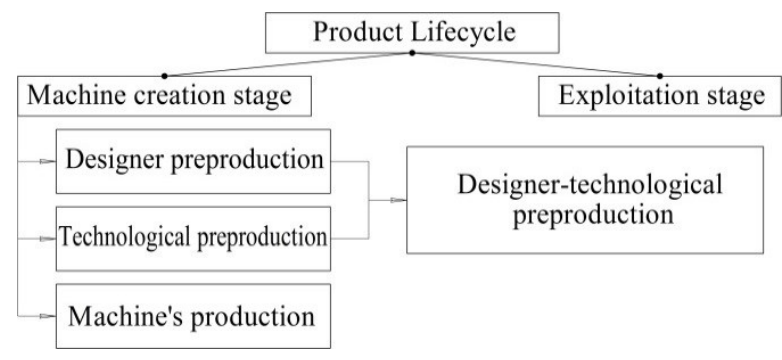

Fig. 1 - Product Lifecycle's stages and substages

On the mechanical engineering development's modern stage the reliability problem becomes actual in connection with designs complication, products machining and assembles, tasks soluble responsibility increasing. The successful decision of this problem depends on the organisational, technical, information and methodological quality components (fig. 2) [3]

Organisational ensuring realises the plans and works complex to reliability parameters, the technical services organisation, economic-legal and administrative mutual relations between machines customer, designer and manufacturer.

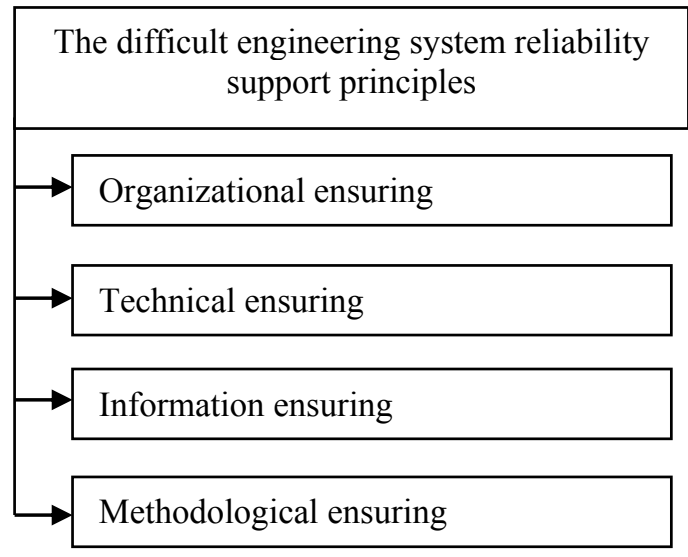

\section{Fig. 2 - The difficult engineering system reliability support principles}

Technical ensuring is defined by the branch fittingout using of applied software, experimental and industrial base, technology perfection, diagnostics and control.

Information ensuring is means and the directions of the collection, accumulation, processes, analysis and using data about systems, failure and defects analysis results design and exploitation processes.
Methodological ensuring covers a theoretical base and engineering-applied methods of systems reliability analysis on the machine life cycle's stages.

At the same time the influence of casting structural components placement on it surface layer defects formation is investigated less. Moreover the technique of technological damages quantitative definition both on casting operation, and during the technological process planning. Therefore these questions require further fundamental theoretical and experimental researches.

\section{The investigation purpose}

The investigation purpose is the casting structural components influence's analysis on the machines details reliability parameters ensuring.

\section{The main part}

Technological process has direct and important influence on reliability parameters. However these communications are difficult, multi-stage and also not obvious (fig. 3) [1-3].

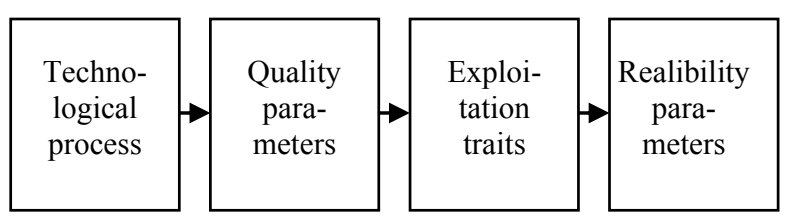

Fig. 3 - The dependence scheme of the reliability parameters about the technological process level

Insufficient quality of the part conception development processes and its production's preparation results in $80 \%$ of all defects emerging during production and parts using. The wrong, hasty and uncompleted technology design and technical requirements nonobservance cause about $60 \%$ of all failures arising during part's warranty period $[2,3]$.

Therefore, ISO 9001:2008 standard underlines the all actions integration. At the same time, the works gravity centre is transferred from function to a process that guaranteed the management's unity, the organizational culture improvement and allows PLM technologies to be effectively implemented $[2,3]$.

The modern reliability theory is based on fundamental mathematics and natural sciences laws [5-10].

There are potential, actual and reliable reliability from technological contention. Potential reliability laids at the design preproduction and technological preproduction. Actual reliability is supplied at the production substage. Exploitation reliability is displayed at the part exploitation stage depending on particular conditions [3].

The tasks, which require a prime definition, are the priority reliability characteristics establishing, its quantitative definition development and part behaviour's forecasting both at the machine creation stage, and at the exploitation stage. 
The part potential reliability defines it maximally reliability achievable value [3]:

$$
\mathrm{P}_{0}=\mathrm{P}_{\mathrm{d}} \cdot \mathrm{P}_{\text {elem }} \cdot \mathrm{P}_{\text {prod. }},
$$

where $\mathrm{P}_{\mathrm{d}}, \mathrm{P}_{\text {elem }}, \mathrm{P}_{\text {prod. }}-$ potential, respectively, the design, furnishing elements and production processes reliability.

The potential design reliability $P_{d}$ is the fact probability that requirements specification which stated in standard documentation specifications remain within the given parameters limits, if sudden failure does not take place.

The potential furnishing elements reliability $\mathrm{P}_{\text {elem }}$. is the fact probability that the elements will work properly during determined time at given power modes and the exploitation conditions:

$$
\mathrm{P}_{\text {elem }}=\mathrm{k}_{\mathrm{i}} \cdot \mathrm{k}_{\mathrm{c}} \cdot \mathrm{k}_{\mathrm{e}},
$$

where $k_{i}-$ coefficient accounting given type elements failure intensity for determined period; $\mathrm{k}_{\mathrm{c}}$ - coefficient accounting exploitation conditions (temperature, humidity etc.); $\mathrm{k}_{\mathrm{e}}$ - coefficient characterising the equipment's type (power, elevating etc.).

The production processes potential reliability $\Pi_{p}$ is defined as the probability that individual technological operations are completed without allowable defects.

In real exploitation conditions, the gap between potential and practical reliability is appreciably given the hidden and obvious defects (40-85\% of the total). These defects are laid down at the machine creating stage (fig. 1), which cause failure during the exploitation stage [1-3].

In this regards potential reliability shouldn't be considered as the machine part condition forecasting's criterion during it manufacturing.

Therefore the interrelations criteria establishing between technological parameters on the substages of machine creation stage and reliability characteristics are the mechanical engineering's important task.

The blanking operation's role is not enough taken into account at modern technological process designing from the reliability position [2,3]. The blanks structure and property should be considered in close combination with the metal heredity from liquid condition. Only $25 \%$ of charge's properties are transferred to the blank. Other $75 \%$ are formed during alloy pouring and curing upon cooling $[2,3]$.

Therefore the reliability parameters formation's analysis on blanking operations has a significant influence to machine parts manufacturing by cutting.

The technological processes infallible implementation's estimated probability (the technological process reliability coefficient) will be described including blanking operations [1]:

$$
\mathrm{P}(\mathrm{t})=\prod_{\mathrm{i}=1}^{\mathrm{m}}\left[1-\left(1-\mathrm{P}_{0}\right) \cdot\left(1-\mathrm{P}_{\mathrm{x}_{\mathrm{i}}}\right) \cdot\left(1-\mathrm{P}_{\mathrm{k}}\right)\right],
$$

where $\mathrm{P}_{0}(\mathrm{t}), \quad \mathrm{P}_{\mathrm{x}_{\mathrm{i}}}(\mathrm{t}) \quad$ - the technological process performance's probability on blanking and intermediate operations (the reliability coefficient on blanking and intermediate operation), $\mathrm{P}_{\mathrm{k}}$ - the parts rejection absence's probability on control operations (the reliability coefficient on control operations).

Hence, the technological processes infallible implementation's estimated probability $\mathrm{P}(\mathrm{t})$ straight depends on the technological process performance's probability on blanking and intermediate operations $\mathrm{P}_{\mathrm{k}}$, $\mathrm{P}_{\mathrm{x}_{\mathrm{i}}}(\mathrm{t})$ and parts rejection absence's probability on control operations $\mathrm{P}_{\mathrm{k}}$.

The physical and chemical heterogeneity which are formed during blank's solidification, is transformed into damages or defects at technological cutting as a structural heredity result in determined cases [2-10].

The castings defects are diverse. Some of them particularly formed on surfaces adjoining with gas phase, by their essence relate to natural roughness. Considerably lot of surface layer's heterogeneities is connected with processes occurring on the firm phase and foundry forms boundaries. Their formation depends on the casting method and the liquid material properties $[11,12]$.

The burnt-on sands, cavities, flashes and cracks are the main blanking's defects.

The burnt-on sand is the metal surface's defect as difficult separated layer on casting which is formed as the form material chemical and physical interaction's result with metal and his oxides.

The gas cavity is displayed as cavity formed with gases allocated from melt

The flash is a defect which results from liquid metal's hit to backlash between the casting crust and the crystallizer wall which is formed owing to the meniscus twist in their contact area.

Hot crack is defect as surface breakage arising during melt solidification.

Cold cracks arise at temperatures lying below metal transition temperature from the plastic deformations area to elastic area.

The medium's aggressive factors impact, working loads, wear and corrosion result to surface layer destruction. Morphology formed structures is connected closely with the surface layer degradation's mechanisms. It allows solving diagnostic tasks according to technical objects current condition's appreciation [11].

The surface layer infringement at parts work consisting of machine from the reasons not connected with operational factors, as well as at transport, storage and assembling, is attributed to flaws. Their presence and characteristics are also specified and are applied for the parts appropriateness evaluation to further operation.

The flaws are named by surface layer local geometrical heterogeneities formed by inadvertent or random impact.

The flaws can be displayed in any asperity deviations dimensional level. Pursuant to ISO 8785:1998 
they are considered as surface recesses scale's independent differentiated on morphology, camber and combined relief elements.

Recess represents defect located below nominal surface. Among them they allocate following heterogeneities types: groove, scratch, crack, blowhole, wane, dent and others.

Cambers are relief elements formed with material located higher than nominal surface. Their modifications are presented by following types: flash, buckle, scale, deposits and others.

The combined flaws can lie both above, and below nominal surface. They involves crater, lap, scoring.

The flaws presence's admissibility depends on the surface functional assignment and their characteristics length, depth, width, height, relative density of the arrangement etc. These parameters are defined by simple measurements on the following definitions basis (ISO 8785:1998) [11]:

surface imperfection length $\mathrm{SIM}_{1}-$ greatest dimension of the surface imperfection, measured parallel to the reference surface;

surface imperfection width SIM $_{\mathrm{W}}$ - greatest dimension of the surface imperfection, measured normal to the surface imperfection length and parallel to the reference surface;

single surface imperfection depth SIM $_{\mathrm{sd}}$ - greatest depth of the surface imperfection, measured from and perpendicular to the reference surface;

combined surface imperfection depth SIM $_{\mathrm{cd}}-$ greatest depth of the surface imperfection, measured from and perpendicular to the reference surface;

single surface imperfection height $\mathrm{SIM}_{\mathrm{sh}}$ - greatest height of the surface imperfection, measured from and perpendicular to the reference surface;

combined surface imperfection height SIM $_{\mathrm{ch}}$ distance between the reference surface and the upper most point of the surface imperfection, measured from and perpendicular to the reference surface;

surface imperfection area $\mathrm{SIM}_{\mathrm{a}}$ - area of a single surface imperfection projected onto the reference surface; total surface imperfection area $\mathrm{SIM}_{t}$ - area equal to the sum of the individual surface imperfection areas, within the agreed limits of discrimination;

surface imperfection number $\mathrm{SIM}_{\mathrm{n}}$ - number of surface imperfection on the total real surface, within the agreed limits of discrimination;

number of surface imperfections per unit area $\mathrm{SIM}_{\mathrm{n}} / \mathrm{A}$ - number of surface imperfections on the specified surface imperfection evalution area A.

The destruction process includes following substages:

1) damages accumulation and material integrity infringements in the voltage formation and deformations area;

2) the tiny cracks development in defect medium ;

3) cracks development and material particles separation at unit loads and motions given on preparation boundaries.
The grains boundaries with big angles have determining role in technological damages formation and alloys destruction between grains boundaries. The various origin distribution boundaries influence to deformation processes and alloys destructions isn't explored. To a considerable extent it is due to failure to take account in existing models the structure boundaries grains and border grains zones structural-phase condition [2].

In practice of the materiology and the mechanical engineering are known methods of the material degree evaluation damageability as the operating time result by direct (methods of weighing, metalgrafia etc.) and indirect (electric resistance, acoustic emission etc.) measurements of metal mechanical specifications without destruction $[2,12]$. The specified ways application for material degradation evaluation as a damages accumulation result during operating time is followed by big errors, as correlation between measured parameters and specifications of structural-phase condition for wide nomenclature of materials ambiguous and is not investigated thoroughly.

From known evaluation methods the most appropriate is material hardness measurement method on determined stages of the operating time. After that, taking into account mechanical specifications correlations, in particular hardness, with structure parameters, material damageability evaluate degree. This method is noninformative and inexact, as between material hardness and it technological damageability correlation weak and not is not always unambiguous.

Therefore necessity in method's development of the material structure evaluation's degradation as a damages accumulation result during the operating time arose which would allow to provide informativeness and accuracy.

The samples structure condition's surveillance quality on the one hand and material's damage of in under study part of samples on the other hand can be carried out by method of LM-hardness developed under the academician A. A. Lebedev direction. By the evaluation criterion not absolute physical quantities values serve, and their derivatives, for example, dissipation of received results of the control performed by the same devices in identical conditions [2]. LM hardness method is easier to realise, applying as mechanical specification hardness on Rockwell. The hardness value is used for parameters indirect evaluation by the structure and other properties.

Homogeneity serves of parameter which integrated describes material condition during the hardness control results processing. Homogeneity is described Vejbull's coefficient $\mathrm{m}$ on Gumbel's known formula [2,13]. Big numerical values of coefficient $m$ concern hardness sizes dispersion's low level, the damageability lowest degree; smaller values, according to logic, define a damageability high degree $[2,13]$.

The Weibull distribution is described by $[2,13]$ :

$$
\mathrm{P}(\sigma)=1-\mathrm{e}^{-\left(\frac{\sigma}{\mathrm{k}}\right)^{\mathrm{m}}},
$$


The Weibull 's homogeneity coefficient is defined to mathematical dependence:

$$
\mathrm{m}=\frac{\mathrm{d}(\mathrm{n})}{2,30259 \cdot \mathrm{S}(\lg (\mathrm{H}))},
$$

where $d(n)$ is characteristic, which is pegged to the measurements amount $\mathrm{n}$;

$$
\begin{gathered}
\mathrm{S}(\ell \mathrm{g}(\mathrm{H}))=\sqrt{\frac{1}{\mathrm{n}-1} \cdot \sum_{\mathrm{i}=1}^{\mathrm{n}}\left(\ell \mathrm{g}\left(\mathrm{H}_{\mathrm{i}}\right)-\overline{\ell \mathrm{g}(\mathrm{H})}\right)^{2}}, \\
\overline{\ell \mathrm{g}(\mathrm{H})}=\frac{1}{\mathrm{n}} \cdot \sum_{\mathrm{i}=1}^{\mathrm{n}} \ell \mathrm{g}\left(\mathrm{H}_{\mathrm{i}}\right) .
\end{gathered}
$$

In researches [2,13] is offered to evaluate the material structure analysis on it damageability $\mathrm{W}$ :

$$
\mathrm{W}=\frac{\mathrm{m}_{\max }-\mathrm{m}_{\mathrm{i}}}{\mathrm{m}_{\max }},
$$

where $\mathrm{m}_{\mathrm{i}}$ is the Weibull homogeneity coefficient's value on i-й lines (planes); $\mathrm{m}_{\max }$ is the maximum Weibull homogeneity coefficient's value for determined measurements series.

However, if unknown microhardness values distribution on sample height (to priority of metal corium hardening), the damageability value of $\mathrm{W}$ is inexpedient to operate. Then the material structural condition's evaluation is implemented on the Weibull homogeneity coefficient's value.

Experimental researches led for casting components analysis influences of the technological damageability formation, as part infallibility parameter.

In sand mold the blank (sizes $165 \times 155 \times 22 \mathrm{~mm}$, material AK21M2,5H2,5 GOST 1853-93) was cast (fig. 4). After crystallization the blank was divided in three samples: with small and big risers and with gate.

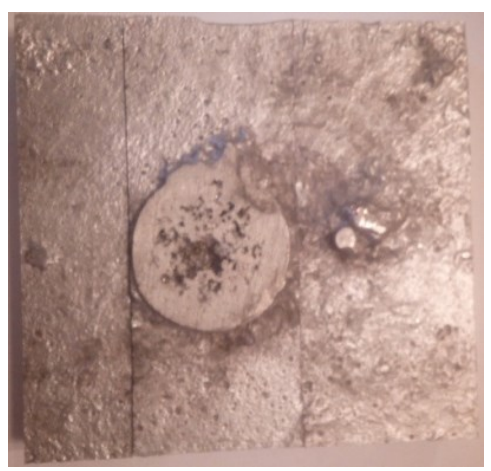

Fig. 4 - The samples for experimental researches:

1 - with small riser; 2 - with gate; 3 - with big riser

Samples end surfaces were processed on universalmilling machine tool $676(\mathrm{t}=0,2-2 \mathrm{~mm}$; Ххв. $=42$ $\mathrm{mm} / \mathrm{min} ; \mathrm{n}=640 \mathrm{~min}^{-1}$ ) by end milling cutter $\varnothing 45 \mathrm{~mm}$ $(z=2)$. Two machining series were carried out. The control of surface layer parameters was implemented after each machining.

The hardness was measured in five cross-sections on distances 2, 4, 7, 12, $17 \mathrm{~mm}$ from the casting's surface (on 30 values) after machining. The measurements implemented for samples 1, 2 (fig. 4) on the device TP5006 GOST $23677-79$ on N's scale by means of ball $\varnothing$ 3,175 with load $588,4 \mathrm{H}$.

The Weibull homogeneity coefficient (m) was computed by equations (5-7). The casting material damageability $\mathrm{W}$ was calculated by equation (8) in medium Mathcad 15 by researches results. The change of damageability W according sample's thickness is presented on the fig. 5 .

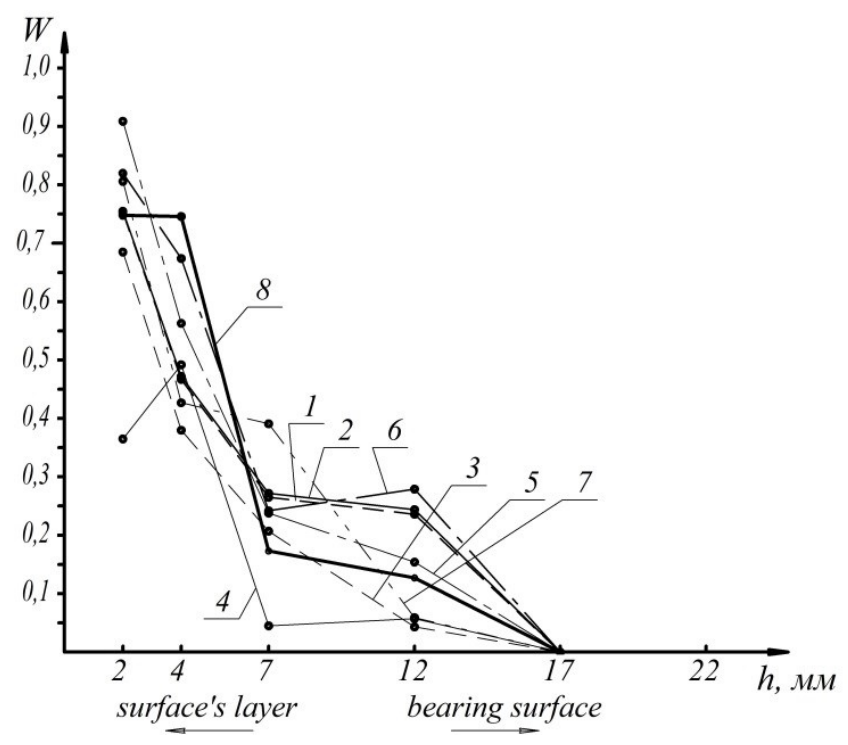

Fig. 5 - The material damageability dependence's schedule $W$ according thickness of samples 1 and 2 (fig. 4): 1, 2 -from small riser fellow for the first and second experience series respectively; 3, 4 -from opposite end surface from riser a fellow for first and second experience series respectively; 5, 6 -for gate from small riser a

fellow for the first and second experience series respectively; 7, 8 -for gate from big riser for the first and second experience series

\section{The results discuss}

The casting damageability structure's experimental researches results showed.

1. The maximum technological damages quantity takes place for the material's zones at a depth up to $2 \mathrm{~mm}$ from surface for sample with gape: more - on the small riser's part, less - on the big riser's part. It is due to specific features of the material hardening process, impurities presence, heterogeneities in surface layer and cavity biased from symmetry axis to the small riser's direction. Results are confirmed by least Weibull homogeneity coefficient's values (m), as well as the damageability largest values $\mathrm{W}$. The Weibull homogeneity coefficient $(\mathrm{m})$ is more for 
sample with small riser, and the damageability value $\mathrm{W}$ is less. It is due to growth of the distance from gape.

2. The damageability stabilisation observed for sample with small riser for the first and second experience series at moving deep into material from 2 to $4 \mathrm{~mm}$. At the same time in the cross-section from gate the damageability is more. It evidences about form design elements influence of to impurities and heterogeneities on casting section distribution. Damageability grows for sample with gate at moving to shrinkage cavity (the second experience series).

3. The damageability values stabilisation takes place at a sample's depth from 4 to $17 \mathrm{~mm}$. It is confirmed by growth of the Weibull homogeneity coefficient's values $(\mathrm{m})$ and approach to the cross-section with quick melt's solidification.

\section{Conclusions}

The main conclusions are made on the held researches grounds.

1. The technological damages evaluation in parts surface layers on blanking operations and after machining is expedient to lead on the hardness characteristics dispersion degree.

2. Parameter of technological damageability $\mathrm{W}$ is offered for the first time as criterion for the parts infallibility evaluation at the machine creation stage.

3. Further research are expedient to extend on more wide parts and materials nomenclature, to introduce a given technique to modern mechanical engineering production's practice.

\section{Список літератури}

1. Кусий, Я. М. Розроблення методу вібраційновідцентрового зміцнення для технологічного забезпечення безвідмовності деталей машин / Я. М. Кусий, А. М. Кук // Східно-Свропейський журнал передових технологій. - 2015. Т. 1, № 7 (73). - С. 41-51. - doi: 10.15587/1729-4061.2015.36336.

2. Кусий, Я. М. Вплив технологічного маршруту оброблення на формування міжзеренної пошкоджуваності виливків / Я. М. Кусий, О. А. Кузін, М. О. Кузін // Східно-Свропейський журнал передових технологій. - 2016. - 1/ 5 (79). - С. 39-47. - doi: 10.15587/1729-4061.2016.59845.

3. Kusyj, J. Vibratory-centrifugal strengthening's influence on failure-free parameters of drilling pumps bushings / J. Kusyj, A. Kuk, V. Topilnytskyy // Technology audit and production reserves. - 2018. - Vol. 1, № 1 (39). - P. 4-12. doi: $10.15587 / 2312-8372.2018 .123838$.

4. McDowell, D. L. Simulation-assisted materials design for the concurrent design of materials and products / D. L. McDowell// Journal of the Minerals, Metals and Materials Society. - 2007. - Vol. 59, № 9. - P. 21-25. - doi: 10.1007/s11837-007-0111-7.

5. Skoog, A. Input data management in simulation-industrial practices and future trends / A. Skoog, T. Pereva, B. Johansson // Simulation Modelling Practices and Theory. 2012. - Vol. 29. - P. 181-192. - doi: 10.1016/j.simpat.2012.07.009.
6. Wang, L. Data representation of machine models / L. Wang // Dynamic thermal analysis of machines in running state. London: Springer-Verlag, 2014. - P. 11-29. - doi: 10.1007/978-1-4471-5273-6 2.

7. McEvily, A. J. Metal failures: mechanisms, analysis, prevention / A. J. McEvily. - John Wiley \& Sons. - 2002. 324 p. - doi: 10.1002/9781118671023.

8. Zohdi, T. I. An introduction to computational micromechanics / T. I. Zohdi, P. Wriggers // Lecture Notes in Applied and Computational Mechanics. Springer, 2005. 198 p. - doi: 10.1007/978-3-540-32360-0.

9. Kundu, T. Fundamentals of fracture mechanics / T. Kundu // CRC Press, Taylor and Francis Group, Boca Raton, FL, USA. - 2008. - $304 \mathrm{p}$.

10. Durham, S. D. Cumulative Damage Models for System Failure with Application to Carbon Fibers and Composites / S. D. Durham, W. I. Padgett // Technometrics. - 1997. Vol. 39, № 1. - P. 34-44. - doi: 10.2307/1270770.

11. Григорьев, А. Я. Физика и микрогеометрия технических поверхностей / А. Я. Григорьев // Беларусская наука. - Минск, 2016. - 247 с.

12. Aftanaziv, I. S. Vibrational-centrifugal surface strengthening of drill and casing pipes / I. S. Aftanaziv, L. I. Shevchuk, L. R. Strutynska, O. I. Strogan // Scientific Bulletin of National Mining University. - 2018. - Issue 5. P. 88-97.

13. Lebedev, A. A. A new method of assesment of material degradation during its operating time / A. A. Lebedev, N. R. Muzyka, N. L. Volchek// Zaliznychnyi Transport Ukrainy. - 2003. - Vol. 5. - P. 30-33.

\section{References (transliterated)}

1. Kusyj, J., Kuk, A. Rozroblennya metodu vibracijnovidcentrovogo zmicznennya dlya texnologichnogo zabezpechennya bezvidmovnosti detalej mashy'n [Method devised to improve technological reliability of machine parts]. Eastern-European Journal of Enterprise Technologies, 2015, 1/7(73), 41-51, doi: 10.15587/17294061.2015.36336.

2. Kusyj, J., Kuzin, O., Kuzin, N. Vply`v texnologichnogo marshrutu obroblennya na formuvannya mizhzerennoyi poshkodzhuvanosti vy`ly`vkiv [The dependence of intergrain damageability of casting on the technological treatment route]. Eastern-European Journal of Enterprise Technologies, 2016, 1/5(79), 39-47, doi: 10.15587/17294061.2016.59845.

3. Kusyj, J., Kuk A., Topilnytskyy, V. Vibratory-centrifugal strengthening's influence on failure-free parameters of drilling pumps bushings. Technology audit and production reserves, 2018, 1/1 (39), 4-12, doi: 10.15587/23128372.2018.123838.

4. McDowell, D. L. Simulation-assisted materials design for the concurrent design of materials and products. Journal of the Minerals, Metals and Materials Society, 2007, 59(9), 2125, doi: 10.1007/s11837-007-0111-7.

5. Skoog, A., Perera, T., Johansson, B. Input data management in simulation-industrial practices and future trends. Simulation Modelling Practice and Theory, 2012, 29, 181-192, doi: 10.1016/j.simpat.2012.07.009.

6. Wang, L. Data Representation of Machine Models. Dynamic Thermal Analysis of Machines in Running Stat. London: Springer-Verlag, 2014, 11-29, doi: 10.1007/978-14471-5273-6_2. 
7. McEvily, A. J. Metal Failures: Mechanisms, Analysis, Prevention. Ed. 2. John Wiley \& Sons, 2002, 480, doi 10.1002/9781118671023

8. Zohdi, T. I., Wriggers, P. An Introduction to Computational Micromechanics. Lecture Notes in Applied and Computational Mechanics. Springer, 2005, 198, doi: 10.1007/978-3-540-32360-0.

9. Kundu, T. Fundamentals of Fracture Mechanics. Boca Raton, FL, USA: CRC Press, Taylor and Francis Group, 2008, 304.

10. Durham, S. D., Padgett, W. J. Cumulative Damage Models for System Failure with Application to Carbon
Fibers and Composites. Technometrics, 1997, 39(1), 34-44, doi: 10.2307/1270770.

11. Grigorjev, A. J. Fizika i mikrogeometrija tehnicheskih poverhnostej [The technical surfaces physics and microgeometry]. Belarusian science. Minsk, 2016. 247.

12. Aftanaziv, I. S., Shevchuk, L. I., Strutynska, L. R., Strogan, O.I. Vibrational-centrifugal surface strengthening of drill and casing pipes. Scientific Bulletin of National Mining University, 2018, 5, 88-97.

13. Lebedev, A. A. , Muzyka, N. R., Volchek, N. L. A new method of assesment of material degradation during its operating time. Zaliznychnyi Transport Ukrainy, 2003, 5, 30-33.

\section{About authors (відомості про авторів)}

Jaroslav Kusyj - PhD, Docent, National University «Lviv Polytechnic», Docent of Mechanical Engineering Department, Lviv, Ukraine; ORCID: http://orcid.org/0000-0001-5741-486X; e-mail: jarkym@ukr.net.

Кусий Ярослав Маркіянович - кандидат технічних наук, доцент, Національний університет «Львівська політехніка», доцент кафедри технології машинобудування, м. Львів, Україна; ORCID: http:/orcid.org/0000-0001-5741-486X; e-mail: jarkym@ukr.net.

Volodymyr Topilnytskyy - PhD, Docent, National University «Lviv Polytechnic», Docent of Machines Designing and Exploitation Department, Lviv, Ukraine; ORCID: http://orcid.org/0000-0002-5191-326X; e-mail: topilnvol@gmail.com.

Топільницький Володимир Григорович - кандидат технічних наук, доцент, Національний університет «Львівська політехніка», доцент кафедри проектування та експлуатації машин, м. Львів, Україна; ORCID: http://orcid.org/0000-00025191-326X ; e-mail: topilnvol@gmail.com.

Please cite this article as:

Kusyj, J. Topilnytskyy, V. Influence of structural components placement on casting technological damages formation. Bulletin of NTU "KhPI". Series: New solutions in modern technologies. - Kharkiv: NTU "KhPI", 2019, 5 (1330), 41-47, doi:10.20998/2413-4295.2019.05.06.

Будь ласка, посилайтесь на иџю статтю наступним чином:

Кусий, Я. М. Вплив розміщення елементів конструкції на формування технологічних пошкоджень виливка / Я. М. Кусий, В. Г. Топільницький // Вісник НТУ «ХПI», Серія: Нові рішення в сучасних технологіях. - Харків: НТУ «ХПІ», 2019. - № 5 (1330). - C. 41-47. - doi:10.20998/2413-4295.2019.05.06.

Пожалуйста, ссылайтесь на эту статью следующим образом:

Кусый, Я. М. Влияние размещения элементов конструкции на формирование технологических повреждений отливки / Я. М. Кусый, В. Г. Топильницкий // Вестник НТУ «ХПИ», Серия: Новые решения в современных технологиях. Харьков: НТУ «ХПИ», 2019. - № 5 (1330). - С. 41-47. - doi:10.20998/2413-4295.2019.05.06.

АННОТАЦИЯ Установлены основные критерии проектирования технологических прочессов. Описаны связи показателей надежности: безотказности, долговечности, ремонтопригодности, сохраняемости с этапами и стадиями жизненного иикла изделия. Проанализированы приниипы обеспечения надежности сложных технических систем для машиностроительного производства. Аргументирован недостаточный уровень исследований относительно влияния размещения конструктивных элементов отливки на формирование дефектов на его поверхности. Рассмотрены разновидности надежности, установлено их место в структуре жизненного иикла изделия и приведены математические зависимости для определения потенциальной надежности. Обоснована нецелесообразность использования потенциальной надежности в качестве критерия прогнозирования состояния изделия во время его изготовления. Подтверждена значимость заготовительных операчий в структуре технологических прочессов механической обработки литых заготовок. Приведена математическая зависимость для оиенки вероятности безотказного осуществления технологического проиесса (коэффициента надежности технологического процесса). Проанализированы виды дефектов и механизмы их формирования в отливках. Охарактеризованы основные виды дефектов литья: пригары, раковины, заливины и трещины. Установлена роль изъянов как нарушений поверхностного слоя при работе деталей в составе изделий. Представлены параметры для контроля изъянов согласно ISO 8785: 1998. Рассмотрены этапы разрушения металла при обработке резанием. Установлено, что важную роль в формировании технологических повреждений и проиессах междузеренных разрушения сплавов имеют гранищы зерен с большими углами. Рассмотрены современные концепции оиенки степени повреждаемости материала как наработки по результатам прямых и косвенных измерений и указаны их основные недостатки. Представлен метод LM-твердости для определения повреждаемости отливок как характеристики безотказности изделия. Описаны технологическое оснащение и методика проведения и осуществления экспериментальные исследований. Представлено обоснование и анализ полученных результатов. Намечены пути дальнейших исследований. Ключевые слова: технологический процесс; надежность; безотказность; литая заготовка; технологическое повреждение; повреждаемость. 